\title{
A Study of the Role of Negotiated Teaching in College English Teaching
}

\author{
Li-hua Tang \\ College of Foreign Language Education of China \\ West Normal University, \\ Nanchong, Sichuan, China \\ 16867933@qq.com
}

\begin{abstract}
Negotiated teaching is a new mode in College English teaching. This paper expounds the forms, functions and existing problems of negotiated teaching in College English classroom, and then puts forward the role played by negotiated teaching in stimulating students' interest in classroom learning and cultivating students ' autonomous learning ability.
\end{abstract}

Keywords-negotiated teaching; autonomous learning; cooperative awareness

\section{INTRODUCTION}

The research of College English teaching mode is based on the characteristics of College English teaching, that is, the number of students is large, the class hours are small, the size of teaching classes is large, and the teaching materials are numerous. Most of the teaching methods are teachers' indoctrination and students' passive learning, ignoring the communication process between teachers and students, autonomous learning, and even the whole learning process of inquiry learning and cooperative learning. Negotiated teaching is a teaching strategy to enable students to participate in classroom teaching decisions, explore teaching objectives and teaching purposes together, and explore ways of activity, form and evaluation. Thus the students become active learners from the passive learners and become participants in the classroom teaching together with the teachers.

\section{The Form of Negotiated Teaching}

\section{A. Negotiation on the goal of teaching content}

The consultation of teaching content objectives is to determine the teaching objectives and content of each class through the guidance of the syllabus and through consultation with the teachers and students. Teachers need to understand individual differences of students, take into consideration their interest in learning and learning ability, and urge students to prepare lessons before class and cultivate autonomous learning habits. Taking the New Horizon College English textbook as an example, there are two texts in each unit, and the emphasis that each text is different. Considering the factors of class hour, students should preview before class. They need to hold familiarity with synopsis, and finally teachers and students decide which is more suitable for classroom teaching.

\section{B. Negotiation of teaching methods}

What methods of teaching activities can be negotiated between teachers and students. They can negotiate anything adopted in a classroom: heuristic, discussion, case, group or personal form, team members, assignment of numbers, assignments and so on. In the process of negotiation, we give students more autonomy and opportunity to train students' independent thinking and conscientious attitude towards learning, and gradually become autonomous and efficient learners.

\section{Negotiation of teaching evaluation}

Teaching evaluation is an important part in the teaching link. Teachers can let students evaluate the teaching content: whether the teaching activities are achieved, whether the teaching objectives are achieved, whether the teaching objectives of this lesson are set and whether teaching activities and contents are reasonable or not. Students become the main body of evaluation. Their active participation is conducive to students' reflection on their learning activities, self-regulation, self-improvement and self-correction. They are very important to improve the quality and efficiency of English learning.

\section{The Role of Classroom negotiated Teaching}

\section{A. Training students' consciousness of participation and the ability of self-study}

In traditional teaching, teachers decide what to learn, how to learn, how to teach, how to practice, and how to evaluate from primary school to university. At the same time, because of the limitations of classroom teaching, students cannot get all the knowledge and training ability through limited classroom teaching. In addition, students' personality differences also require teachers to carry out corresponding training in listening, speaking, reading, writing and translation. In negotiated teaching, students should first realize that they should be involved in classroom teaching, and decide on their learning process, learning objectives, contents and steps, and so on, and choose teaching methods and strategies. In this way, they can monitor the process of language acquisition and the effect of their learning. With the awareness of participation in consultative teaching, students can guide their self-study. The learners can rely on their individual learning styles, positive learning attitude and good learning ability to set the learning 
objectives independently under the guidance of teachers. They can assess their own learning, study the learning objectives of the course and complete the implementation through individual activities or with others' cooperation. They negotiated what to learn in the classroom, what method to use, and what kind of teaching purpose. Once the students make their own decisions, they will be able to study consciously, supervise the learning process, control the learning speed, and implement the learning evaluation. And the independent study of our present university classroom is carried out under the guidance of teachers. Teachers design different teaching tasks at different

Due to the influence of Chinese traditional education, students' dependence on teachers is strong. Their learning is lack of planning. Even if there are plans, it is hard to ensure that the classroom efficiency is not high enough. In negotiated teaching, teachers rely on their own thinking wisdom, rich experience and professional skills to give necessary guidance and necessary supplement at the right time, so as to make students' knowledge construction more complete. Teachers guide students to find problems and difficulties in learning, and encourage students to solve problems through every possible way, such as using a dictionary, a textbook, a search for related materials on the Internet, discussion or negotiation in the form of a group. This can cultivate students' ability to explore and learn, and have a deeper understanding of the language they have learned. At the same time, it can also make students learn to learn independently and rely less on teachers. Teachers can put forward the related issues in the first book of New Vision College English textbooks "Deep Concern". "What is a generation gap?", "How can the older and the younger generation have real communication with and understand each other?" Through the collection of materials and communication with others, students can solve the above problems. At the same time, they also master the focus of this unit. Obviously, inquiry learning ability is essential in negotiated teaching.

\section{B. Cultivating students' ability to communicate and collaborate}

In the process of consultation teaching, it is essential to cultivate students' cooperative learning ability. The collaborative learning is a learning strategy to help students learn in the form of group participation, under certain incentive mechanism to obtain the maximum individual or group learning results and achieve the common goal of cooperative learning. In the inquiry learning under the guidance of teachers, sometimes they found the problem is similar, so it can be activated through group discussion. Teaching content will be assigned to each group for different tasks. They may discuss the division of labor and cooperation between team members, sharing resources and information sharing, responsibility, honor to complete the task. In the whole process of cooperation, they can inspire each other, use their experience to build their self-confidence and share their learning and avoid similar mistakes in the learning process. Thus, their collective wisdom makes the learning effect more ideal. For example, in the teaching of reading, the group cooperative learning of reading teaching can be divided into three steps. First, teachers arrange the preview according to the subjects and genres of the text, including the background of knowledge collection, the collection of information, the role of repetition, drama, etc; secondly, in classroom teaching, the teacher inspect the relevant background, performing skits and other self; finally the teacher was preparing training, literal reading, deep reading and after-school activities. In short, cooperative learning can cultivate the cooperative learning ability of students, increase students' individual and social members of the exchange and communication ability, has a positive effect on improving students' learning achievement and the integrated use of knowledge, and reinforces the importance of deliberative teaching.

\section{THE PROBLEMS AND SOLUTIONS IN THE ClASSROOM Negotiated TEACHING}

\section{A. Students participate in the classroom negotiation passively}

Students are accustomed to the traditional classroom teaching mode. In this mode, teachers are imparting of knowledge, and students are the recipients of knowledge. Students' learning is carried out around teachers' teaching. It makes the students in the passive, obedient learning status, without the autonomy of learning, and the self-consciousness and initiative of learning cannot be played. In the negotiation classroom, this makes the students show a bad attitude, lack of self-confidence, and do not take the initiative to participate in consultation activities. In view of these phenomena, as teachers should encourage students to ask questions, then guide them to prepare for the class. In the negotiation, teachers encourage them to express these problems in the classroom and to communicate and interact with other students.

\section{B. Students are less aware of their learning ability}

Most students rely too much on teachers in class. They always want teachers to teach them, give those answers, help them analyze and solve problems. They seldom use their abilities to acquire language knowledge. At the beginning of the consultation teaching, the first thing to do is to cultivate the students' enthusiasm and ability to acquire knowledge. There are a series of methods, such as forming the habit of university learning environment, adapting to the teaching mode of University, changing the traditional learning habits, improving learning methods and learning strategies, cultivating students' habit of querying, doing, moving their mouths and moving their brains. In a word, students will gradually get used to acquiring knowledge through their own efforts, and no longer rely too much on teachers.

\section{CONCLUSION}

Negotiated teaching in College English classroom is a new teaching model. It not only trains students to dare to challenge, innovate, and find solutions to problems in active participation, but also cultivates students' autonomous learning and collaborative learning ability. At the same time, students' self confidence in learning is enhanced, and their sense of cooperation and responsibility are enhanced. By way of mutual discussion, communication and learning, they learn to use learning strategies and improve their ability to use language. At the same time, negotiated teaching is also the common participation of teachers and students in classroom teaching, 
taking responsibility together, becoming the decision-makers in the classroom teaching, and playing different roles in the classroom. Teachers are engaged in the design, organization, participation and evaluation, while the students are participants, negotiators, and resource sharing. Negotiated teaching reflects the independence and interaction of classroom teaching, encouraging students to learn independently, arousing students' learning enthusiasm and inspiring students' exploration spirit.

The classroom negotiated teaching makes the students become participants, supervisors and evaluators of classroom teaching. It helps students to reflect and evaluate their learning motivation, learning strategies and learning effects. Students find problems actively, take measures to solve problems in time, and constantly adjust the learning process to improve the efficiency of foreign language acquisition.

\section{ACKNOWLEDGEMENT}

The paper was supported by funded projects: 2017 China West Normal University Teachers Elite fund project number. (No. 17YC073).

\section{REFERENCES}

[1] Xuehui Liu. Second language acquisition in a classroom setting: theoretical frameworks and analytical units [J] Foreign language and foreign language teaching,(6):25-29 2005

[2] Xuehui Liu. Negotiation, interaction and timely output: a timely exploration of classroom language [J] Foreign language and foreign language teaching, (11):25 2007.

[3] Junping Zhou. Teacher talk and second language acquisition [J], Foreign language teaching (5):69-73 2006

[4] Wenli fang. Meaning negotiation and foreign language focused Taskbased Teaching $[\mathrm{J}]$ Foreign language and foreign language teaching (1):23-27. 2005

[5] Aijun Liu. Research on listening and speaking teaching mode in Multimedia Network Environment [J] Foreign language world (5):6 364. 2009

[6] Liuheng, Zhen Zhinian. Study on English Listening Classroom Teaching of Higher Vocational Students' negotiating [J] Journal of Jixi University (5): 8. 2008

[7] Kefu Lang, Wangling. Research on the motivation of autonomous learning under the Internet Teaching Model [J] Foreign language world (3): 16. 2010

[8] Dingfang Su. Comprehensive curriculum objectives and quality of English Majors--a review of the third foreign language teaching competition held by the foreign teachers' Association Cup in China[J] Foreign language world(2):43-49. 2003

[9] Dingfang Su. College English teaching competition and teacher development [J] Foreign language world (2): 34-41. 2012 